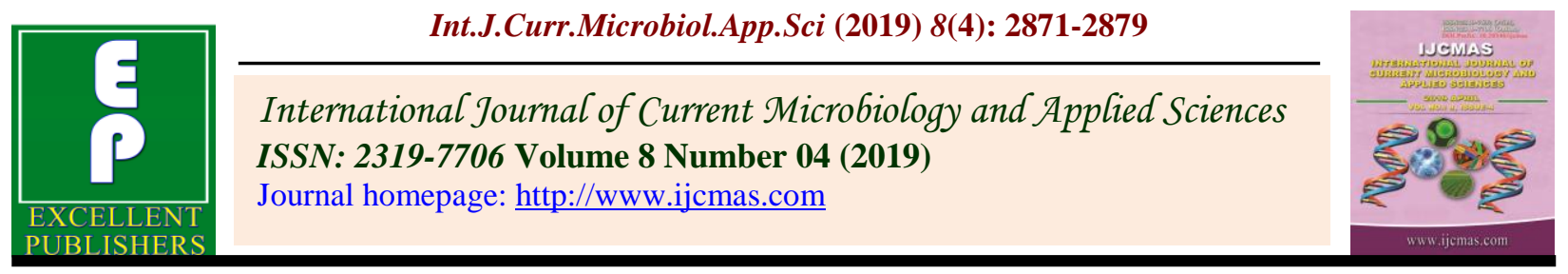

Original Research Article

https://doi.org/10.20546/ijcmas.2019.804.335

\title{
Ganoderma Species of Mizoram, India
}

\author{
Zohmangaiha, Josiah MC. Vabeikhokhei, John Zothanzama* and H. Lalrinawmi \\ Department of Environmental Science, Mizoram University, Aizawl 796004, Mizoram, India \\ *Corresponding author
}

\begin{tabular}{|c|c|}
\hline & A B S T R A C T \\
\hline Keywords & $\begin{array}{l}\text { In the present study investigated the taxonomic identities and phylogenetic } \\
\text { relationships of Ganoderma species isolated from different locations within }\end{array}$ \\
\hline $\begin{array}{l}\text { Basidiomycota, } \\
\text { Internal transcribed } \\
\text { spacer, Mizoram }\end{array}$ & $\begin{array}{l}\text { Mizoram, India using a combination of morphological and molecular approaches. } \\
\text { Six Ganoderma isolates were identified through morphology and further } \\
\text { confirmed by molecular phylogenetic analysis using nuclear ribosomal DNA }\end{array}$ \\
\hline Article Info & sequences, including both the internal transcribed spacers (ITS1 and ITS2) and the \\
\hline $\begin{array}{l}\text { Accepted: } \\
\text { 20 March } 2019 \\
\text { Available Online: } \\
10 \text { April } 2019\end{array}$ & $\begin{array}{l}\text { 5.8S gene region. The } 6 \text { species of Ganoderma identified to the species level } \\
\text { based on morphology and fungal DNA sequences were G. lingzhi, } G \text {. } \\
\text { mastoporum, G. mizoramense, G. multipileum, G. subresinosum, and } G \text {. } \\
\text { williamsianum. }\end{array}$ \\
\hline
\end{tabular}

\section{Introduction}

Ganoderma species belong to the kingdom of Fungi, the division of Basidiomycota, the class of Homobasidiomycetes, the order of Aphyllophorales, the family of Polyporaceae, (Ganoderma taceae) and the genus of Ganoderma (Wasser and Weis, 1999). They have a woody or leathery feel and the presence of pores are obvious characteristics that distinguish polypores from other common type of mushrooms. They degrade the wood and produce a fruiting body (or conk) on the surface of the wood. Ganoderma species are among those fungi that can thrive under hot and humid conditions and are commonly found in sub tropical and tropical regions (Moncalvo and Ryvarden, 1998).
Although they are not classified as edible, several types of Ganoderma products are used for medical purposes including ground fruiting bodies or mycelium processed into capsule or tablet form; extracts from fruiting bodies or mycelium dried and processed into capsule or tablet form, Ganoderma beer and Ganoderma hair tonics (Jong and Birmingham, 1992) as well as many other products are made from various Ganoderma species. Within the genus Ganoderma, over 250 taxonomic names have been reported worldwide including $G$. adspersum, $G$. applanatum, G. australe, G. boninense, $G$. cupreum, G. incrassatum, G. lipsience, $G$. lobatum, G. lucidum, $G$. oerstedii, $G$. oregonense, $G$. pfeifferi, $G$. platense, $G$. resinaceum, $G$. sessile, $G$. sinense, $G$. 
tornatum, G. tsugae and G. webrianum. (Moncalvo et al., 1995).

Ganoderma species identification and circumscriptions have often been unclear and taxonomic segregation of the genus has been controversial (Moncalvo et al., 1995). A number of Ganoderma collections and species have been misnamed. This is because the presence of heterogenic forms, taxonomic obstacles and inconsistencies in the way the genus has been subdivided (Mueller et al., 2007). Since Ganoderma species are genetically heterogeneous, a wide range of genetic variationhas been reported and caused by out crossing over generations and different geographical origins (Miller et al., 1999, Pilotti et al., 2003).

This has led to variation in their listed morphological characteristics, even within same species (Hong et al., 2001). Environmental factors, variability, inter hybridization and individual morphological bias, mean identification of Ganoderma species is difficult (Zheng et al., 2009). Naming a species within this genus is confused and traditional taxonomic methods based on morphology are inconclusive for establishing a stable classification system for Ganoderma species (Hseu et al., 1996, Hong et al., 2004). Hence an uncertain nomenclature has resulted.

This confusing situation is mainly the result of different authors using various criteria during identification. Some authors strictly only focus on host-specificity, geographical distribution and macro morphology of basidiomes, while other authors only focus on spore characters as the primarily taxonomic characters (Sun et al., 2006).

Ganoderma lucidum (Bisht, 2011) and Ganoderma mizoramense (Zothanzama et al., 2017) have been reported in Mizoram. The present investigation is a first detailed report on the morphology and molecular phylogeny of Ganoderma in Mizoram (Fig. 2).

\section{Materials and Methods}

\section{Collection and preservation of specimens}

Samples of fruiting bodies or host substrate (wood, stumps or branches) were collected and kept in air-tight containers or plastics bags and kept cool until brought into the laboratory. Photograph of each sample collected were taken in the field and in the laboratory (Prasher, 2015). The specimens are preserved by air drying and deep freezing. Voucher numbers are given to the specimens and stored in the Department of Environmental Science, Mizoram University.

\section{Identification of specimens}

The collected specimens were identified according to standard macroscopic and microscopic characteristics through consultation with appropriate literature (Gilbertson and Ryvarden, 1986; Núñez and Ryvarden, 2000).

For microscopic study, thin sections of dried specimens were taken with a sharp razor blade and were mounted in $3 \% \mathrm{KOH}$ solution and stained in $2 \%$ aqueous phloxine. Sections were mounted in Lactophenol or $60 \%$ lactic acid + cotton blue. Spore prints of the collected specimens were taken by cutting a section of the pore layer, placing it on a piece of white paper, and covering it.

\section{Molecular analysis}

DNA was extracted from tissue removed from the inside of fruiting bodies using a CTAB extraction. A small amount of tissue from the inside of the fruiting body was added to a sterile $1.7 \mathrm{ml}$ microcentrifuge tube with glass 
beads and $500 \mu \mathrm{L}$ of CTAB lysis buffer. The centrifuge tube was then vortexed for a minute homogonize lyse fungal cells. For drier and harder fruiting bodies, the tissue was vortexed for 2 minutes to allow for a better homogonization of the tissue. The tubes were then briefly centrifuged to move the larger tissue segments to the bottom of the tube and then the supernatant was transferred to another tube. The new microcentrifuge tube was then placed into a $65^{\circ} \mathrm{C}$ hot water bath to further lyse the cells. After 20 minutes, the tubes were removed and $500 \mu \mathrm{L}$ of chloroform were added to the tube, mixed and then centrifuged at 13,000 rpms for 5 minutes. The top layer of the supernatant was then transferred to a new microcentrifuge tube. The amount of liquid transferred was then measured and two thirds of that amount was added of isopropanol stored in a minus 20C freezer. The tube was then incubated for 5 minutes at room temperature before being centrifuged for 7 minutes at $15,000 \mathrm{rpm}$. The supernatant was removed and $500 \mu \mathrm{L}$ of $70 \%$ ethanol was added. The tubes were centrifuged again at 15,000 rpm for 3 minutes and the supernatant was removed. The tubes were left open in a hood to allow the last of the ethanol to evaporate before the DNA pellet was re-suspended in $100 \mu \mathrm{L}$ of sterile water.

PCR reactions were setup in $0.2 \mathrm{ml}$ centrifuge tubes that contained $12.5 \mu \mathrm{l}$ GoTaq Green

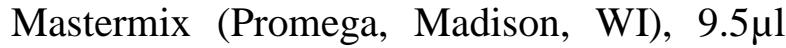
nuclease free water, $1 \mu l$ forward primer $(5 \mathrm{M})$, $1 \mu 1$ reverse primer $(5 \mathrm{M})$ and $1 \mu l$ of fungal DNA template for a total reaction volume of 25.5 $\mu 1$. PCR was performed using primers ITS1-F (5'-CTT GGT CAT TTA GAG GAA GTA A-3') ITS4(5'-TCCTCCGCTTATTG ATATGC-3') (White et al., 1990) with the following parameters; $94^{\circ} \mathrm{C}$ for 5 minutes, followed by 35 cycles of $94^{\circ} \mathrm{C}$ for 1 minute, $52^{\circ} \mathrm{C}$ for 1 minute and $72^{\circ} \mathrm{C}$ for 1 minute with a final extension step of $72^{\circ} \mathrm{C}$. PCR amplicons were verified by electrophoresis on a $1 \%$ agarose gel with SYBR green and visualized on a Gel Documentation System. Sequencing was performed using both primers by using Sanger sequencing using a DNA sequencer. Consensus sequences for contigs were trimmed and aligned using Bioedit sequence alignment editor (Hall, 1997). Sequences were then compared to those in GenBank database using the BLASTn (Altschul et al., 1990) search tool for similarities and were submitted to Genbank. The sequences were then aligned with Clustal W (Larkin et al., 2007) and the phylogenic tree was established using Maximum Likelihood in Mega 7 (Kumar et al., 2015) software with the available sequences representing all the species of Ganoderma collected within Mizoram.

\section{Phylogenetic analysis}

Phylogenetic analysis was conducted based on the ITS gene data using both Maximum Likelihood (ML) and Neighbor Joining (NJ) approaches. ML and NJ searches were carried out using MEGA7. Alignment gaps were treated as missing data. NJ trees were constructed based on the total character differences and bootstrap values were calculated from 1,000 replications.

\section{Results and Discussion}

\section{Morphological identification}

Morphological identification of the 6 fungi from Mizoram was first carried out according to characteristics of the spores, and reproductive structures if discernible using previously described methods (Barnett and Hunter 1998, Zothanzama et al., 2017).

\section{Morphological details}

\section{Ganoderma subresinosum}

Basidiocarp annual, stipitate laterally, applanate, rigid, becoming hard corky and 
woody hard when dry. Pileus $6-14 \mathrm{~cm}$ broad and upto $0.6 \mathrm{~cm}$ thick at the lateral, surface irregular/wrinkled, blackish blue, pore surface white to creamy in colour, sometimes extends upto the edge. Stalk stout upto 3 - $5 \mathrm{~cm}$ long, essentric (off-centric). Basidia club-shaped, broad at the base and narrower at top, tetrasterigmatoid, $2-4$ x $6.8-8 \mu \mathrm{m}$. Sporeprint creamy to off-white, difficult to obtain, mostly obtained through section cuttings.

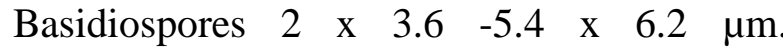
Ellipsoidal, doubled wall.

Specimen Voucher No- MZU JZ014, MZU JZ067

Site of collection- Mizoram University Campus.

\section{Ganoderma williamsianum}

Basidiocarp sessile, annual or perennial, applanate and slightly ascending then more or less ungulate, sulcato-zoned, becoming stepped at the margin, at first pale warm brown, and reddish brown with age. Pileus $1.5-7(-9) \mathrm{cm}$ in radius, upto $15 \mathrm{~cm}$ broad, or with a subdiscoid base, semicircular in outline. Tubes $35 \mathrm{~mm}$ long, 120-200 $\mu \mathrm{m}$ wide, dark brown, pores 60-70 $\mu \mathrm{m}$ wide, minute. Flesh 3-15 mm thick at the base, dense, firm, heavy, uniformly dark brown, dark. Spores 11-14(-15) x 8-10.5 $\mu \mathrm{m}$, ellipsoid and double walled.

Specimen Voucher No- MZU JZ060.

Site of collection- Dampa

\section{Ganoderma lingzhi}

Basidiocarp sessile, rigid, corky to woody, crustose, dark brownish to blackish brown, irregular, rugose $4-8 \mathrm{~cm}$ wide, sometimes shows erect slender finger like projection. Stipe absent. Pore surface smooth, creamy when fresh and becomes pale brown when aged or bruised, pores circular to somewhat ovoidal, 1.5 - $2.5 \mathrm{~mm}$. Basidiopores 1.53-2.2 $\mathrm{x}$ 2.56-2.94 $\mu \mathrm{m}$, more or less ellipsoidal, sometimes with truncate end, double walled. Basidia 2.24 - 2.91 x 3.41-4.6 $\mu \mathrm{m}$, elongated, broadly clavated, tetrasterigmatic.

Specimen Voucher No- MZU JZ049.

Site of collection- Hmuifang.

\section{Ganoderma mastoporum}

Basidiocarp sessile, rigid, corky to woody, crustose, dark brownish to blackish brown, irregular, rugose $4-8 \mathrm{~cm}$ wide, sometimes shows erect slender finger like projection, Stipe absent. Pore surface smooth, creamy when fresh and becomes pale brown when aged or bruised, pores circular to somewhat ovoidal, 1.5 - $2.5 \mathrm{~mm}$. Basidiopores 1.43-2.2 $\mathrm{x}$ 2.56-2.94 $\mu \mathrm{m}$, more or less ellipsoidal, sometimes with truncate end, double walled. Basidia 2.24 - $2.91 \times 3.41-4.6 \mu \mathrm{m}$, elongated, broadly clavated, tetrasterigmatic.

Specimen Voucher No- MZU JZ020.

Site of collection- Dampa.

\section{Ganoderma mizoramense}

Mature basidiocarp annual, pileate, stipitate, applanate, soft and leathery when fresh and woody to corky when dried, semi-circular, irregular surface, dark brownish to dark reddish brown, homogenous context structure 2-20 mm, upto $29 \mathrm{~cm}$. Pileus upper surface reddish brown when fresh, liver brown when dry, surface hard, margin white, lower surface white when fresh, pale brown when dry. Stipe sometimes present and often prominent; twisted and irregular. Pore surface smooth, creamy to snuff brown when dry, pores 4-5 per $\mathrm{mm}$, round to somewhat slightly oval, 187-278 $\times$ 134-228 $\mu \mathrm{m}$. Basidia tetrasterigmatic. Basidiospores ellipsoid with a truncate base, $10-12.5 \times 6-9 \mu \mathrm{m}$. 
Specimen Voucher No- MZU-G, UMN-MZ5 Site of collection- Mizoram University Campus.

\section{Ganoderma multipileum}

Basidiocarps annual, centrally to laterally stipitate, applanate, upto $15 \mathrm{~cm}$ or more broad, upper surface with thin varnished crust at maturity, yellow at the margin in actively growing specimens; pore surface creamy white at first, becoming light buff, staining dark purple-brown on bruising or when aged, pore circular to angular, $4-1 \mathrm{~mm}$. Basidia $12-$ $23 \times 10-11 \mu \mathrm{m}$, broadly ellipsoid to barrelshaped, tetrasterigmatic, with a basal clamp. Basidiopores 7-11 x 6-8 $\mu \mathrm{m}$, often variable in length, ellipsoid, truncate at apex, wall two layered.

Specimen Voucher No- MZU JZ021, MZU JZ078.

Site of collection- Hmuifang, Reiek.

\section{Molecular analysis}

In addition to the morphological characterization, molecular analyses were carried out to confirm the identification of 6 representative fungal isolates from the Mizoram. The ITS1-5.8S-ITS2 sequences of these isolates were compared to 14 corresponding sequences of reference fungal taxa in the database. (Table-1) and the List of Species, VoucherNos, GenBank Accession Nos. and Locality used for the analysis is also given (Table-2).

The analysis involved 20 nucleotide sequences (Figure 1). In the maximum Likelihood tree generated, the specimens of the different species of Ganoderma clustered with their related species with high support value.

Blast search showed that isolate JZ14 is 99\% identical to G. subresinosum (KJ654374) with query coverage of 99\%. Isolate JZ20 was likely to be G. mastoporum with $99 \%$ identity with AJ627585 (98\% coverage) and JQ409361 (99\% coverage). Blast search showed that isolate JZ60 is $97 \%$ identical to G. williamsianum (KU219995) with query coverage of $98 \%$. Schizophyllum commune (KX958030) was used as an out-group.

The evolutionary history was inferred by using the Maximum Likelihood method based on the Tamura-Nei model. The tree is drawn to scale, with branch lengths measured in the number of substitutions per site.

The analysis involved 20 nucleotide sequences. All positions containing gaps and missing data were eliminated. Evolutionary analyses were conducted in MEGA7.

Table.1 List of Ganoderma species collected within Mizoram

\begin{tabular}{|c|c|c|c|c|c|}
\hline \multicolumn{6}{|c|}{$\begin{array}{l}\text { Sl.NoVoucher No.NCBI Accession No.Morphological identificationBlast match Max } \\
\text { identity }\end{array}$} \\
\hline \multirow{2}{*}{\multicolumn{6}{|c|}{$\begin{array}{c}\text { JZ14 } \\
\text { MZU-G/ UMN-M75 }\end{array}$}} \\
\hline & & & & & \\
\hline \multicolumn{2}{|r|}{ JZ21 } & MG450346 & \multirow{4}{*}{$\begin{array}{l}\text { Ganoderma multipileum } \\
\text { Ganoderma mastoporum } \\
\text { Ganoderma williamsianum } \\
\text { Ganoderma lingzhi }\end{array}$} & KX055556 & \multirow{2}{*}{$\begin{array}{l}97 \% \\
98 \%\end{array}$} \\
\hline \multirow{3}{*}{$\begin{array}{l}4 \\
5 \\
6\end{array}$} & \multirow{2}{*}{$\begin{array}{l}\text { JZ20 } \\
\text { JZ60 }\end{array}$} & MG448604 & & JQ409361 & \\
\hline & & МH071336 & & KU219994 & $99 \%$ \\
\hline & JZ49 & MH479057 & & AB811848 & $98 \%$ \\
\hline
\end{tabular}


Table.2 List of species, voucher, genbank accession nos. and locality used for the analysis

\begin{tabular}{|l|}
\hline Species VoucherGenBankAccession Nos.Locality \\
\hline Ganoderma subresinosumT162KJ654376Indonesia \\
Ganoderma mastoporumPM2JQ409361Malaysia \\
Ganoderma philippiiE7425AJ608713Indonesia \\
Ganoderma wiiroenseUMN-20-GHAKT952361Ghana \\
Ganoderma merredithae124FL(ALL)KY708881United States \\
Ganoderma tsugaeUOC KAUNP MK26KP794598Sri Lanka \\
Ganoderma sichuanenseHMAS42798JQ781877China \\
Amaurodermarugosum CH8-1MG021113China \\
Schizophyllum commune15R-5-F01KX958030China \\
Ganoderma multipileumG82KX055556China \\
Ganoderma multipileumG74KX055554China \\
Ganoderma williamsianum Yuan 5417KU219995China \\
Ganoderma tropicum Yuan 3490JQ781880China \\
Ganoderma lingzhiMQN002AB811848Japan
\end{tabular}

Fig.1 Ganoderma species collected in Mizoram

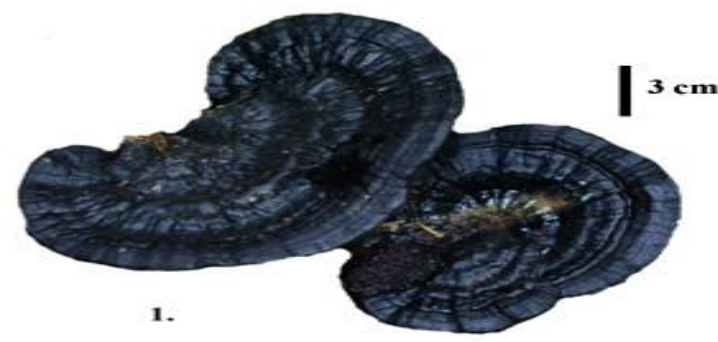

1.

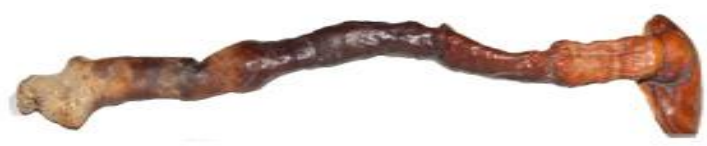

$3 \mathrm{~cm}$

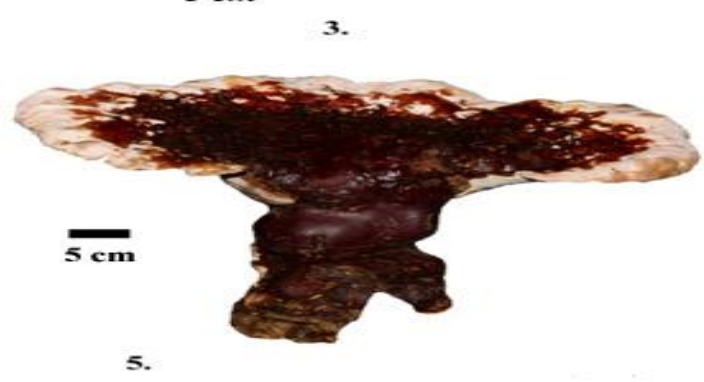

6

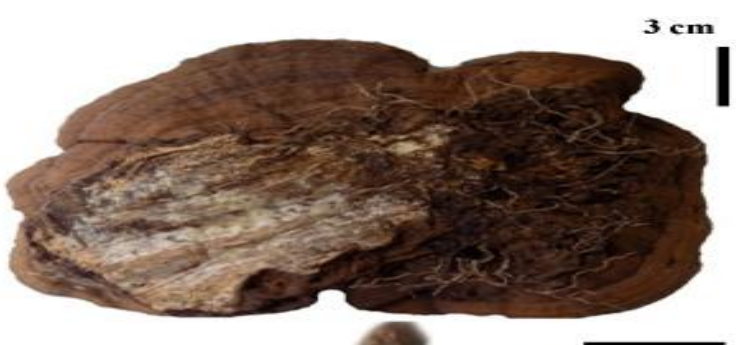

2.

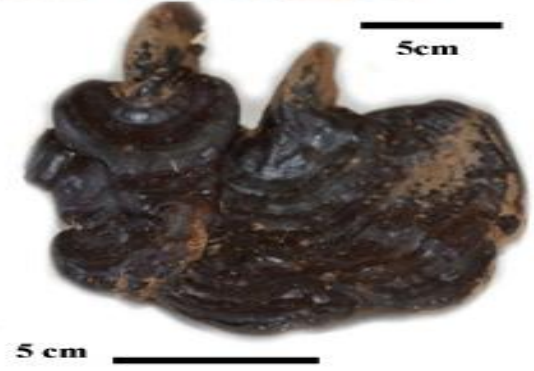

4.

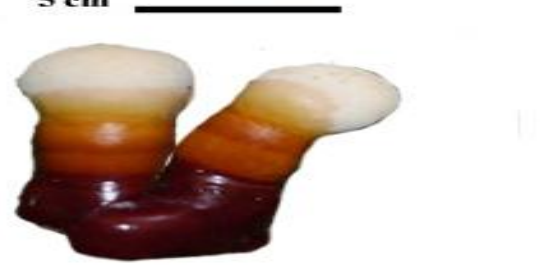

1. Ganoderma subresinosum, 2. Ganoderma williamsianum, 3. Ganoderma lingzhi, 4. Ganoderma mastoporum 5. Ganoderma mizoramense, 6. Ganoderma multipileum 
Fig.2 Phylogenetic tree

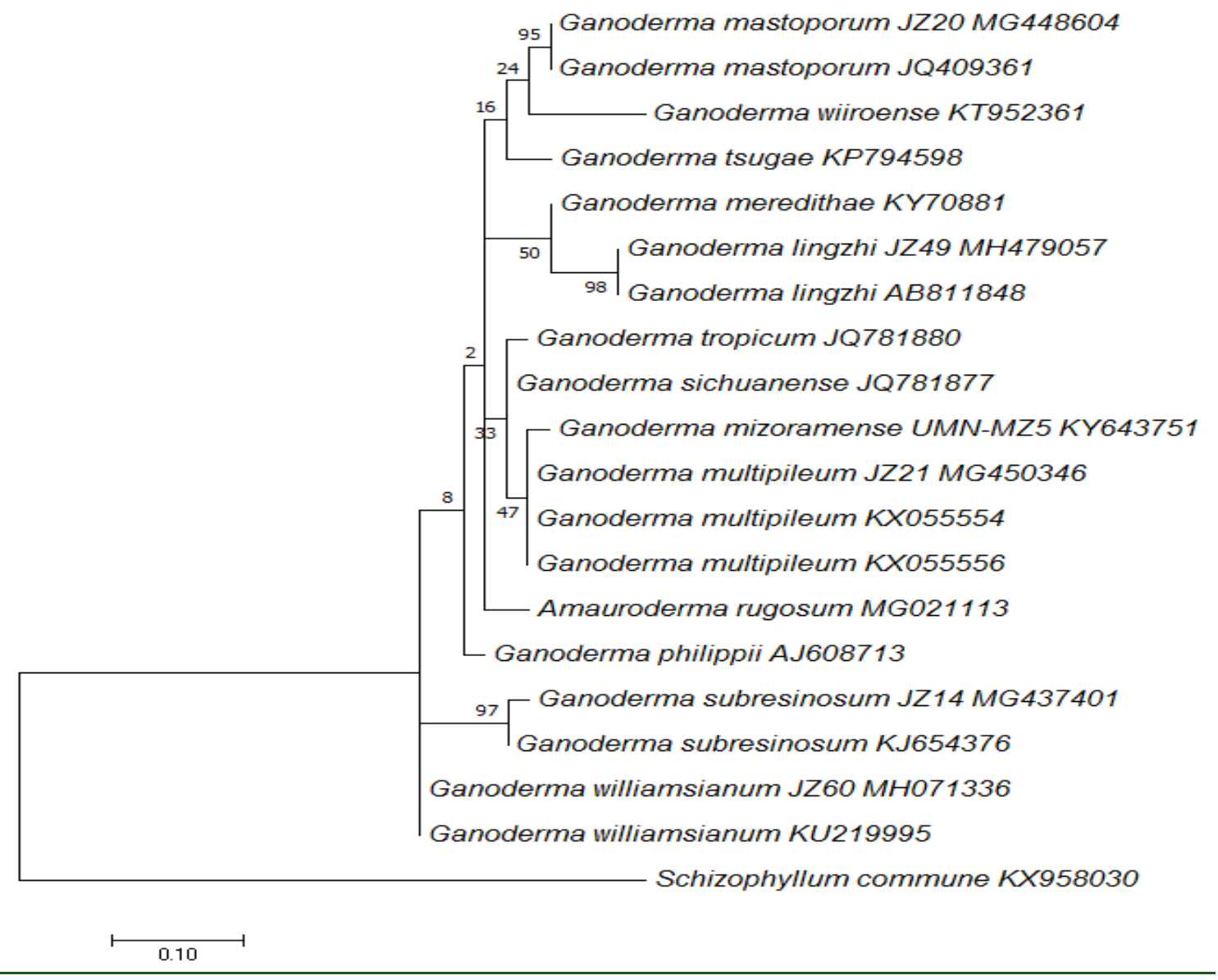

Most of the major polygenetic relationships were congruent based on M.P (Maximum Parsimony), N.J (Neighbour Joining). Six species of Ganoderma have been collected and identified from different locations within Mizoram. Ganoderma mizoramense is a new species which was recently identified and described (Zothanzama et al., 2017).JZ14 (MG437401) has slight variation in the neucleotide sequence (12 neucleotides differences) compared to G. subresinosum KJ654376.JZ60 (MH071336) collected from Dampa Tiger Reserved forest is quite similar to G. australe, but the phylogenic analysis indicates that it lies close to $G$. williamsianum. Only two sequences of $G$. williamsianum were found in the NCBI Genbank for comparison.
Molecular techniques have been successfully used for identifying fungi in recent studies. Culture-independent DNA methods, such as denaturing gradient gel electrophoresis (DGGE, Muyzer Gerard et al., 1998), terminal restriction fragment length polymorphism (T-RFLP), and ITS sequencing, have been developed for the investigation of complex microbial communities. Our study also shows that molecular identification based on ITS sequences can be used to complement or verify morphological identification of unknown fungi.

Among the many wood rotting fungi in Mizoram, Ganoderma species are selected because they are the most common studied 
species of wood rotting fungi. Some are known to cause disease while some has been used for centuries for promotion of good health longevity. Some Ganoderma species have been reported to have various pharmalogical activities such as hepatoprotective, anti-diabetic, antihypertensive, cardioprotective, anticancer, antioxidant etc. More analysis and study should be done for species such as G.mizoramense which is the new species which may possess pharmalogical properties.

\section{Acknowledgements}

This work was supported by the Department of Environmental Science, Mizoram University, India. We would like to thank Biotech Hub, Department of Biotechnology (Mizoram University) for advice concerning DNA extraction, PCR equipment and organization of sampling trips.

\section{References}

Altschul, S., Gish W., Miller, W., Myers, E.W. and Lipman, D.J. 1990. Basic Local Alignment Tool. J. Mol. Biol., 215, 403-410.

Barnett, H.L., and Hunter, B.B. 1998. Illustrated Genera of Imperfect Fungi. $4^{\text {th }}$ Edition, APS Press, St. Paul, 218 p.

Bisht, N.S., 2011. Wood decaying fungi of Mizoram. Department of Environment and Forest, Govt of India. 196 pp.

ClustalW and ClustalX version 2. 2007.

Larkin MA, Blackshields G, Brown NP, Chenna R, McGettigan PA, McWilliam H, Valentin F, Wallace IM, Wilm A, Lopez R, Thompson JD, Gibson TJ and Higgins DGBioinformatics, 2007 23(21): 2947-2948.

Gilbertson, R.L., Ryvarden, L., 1986. North American Polypores. 1:1-443.

Jong, SC., Birmingham JM. 1992. Medicinal benefits of the mushroom Ganoderma. Adv Appl Microbiol. 37: 101-134.

Kumar, S., Stecher, G., Li M, Knyaz, C., and Tamura, K. 2018. MEGA X: Molecular Evolutionary Genetics Analysis across computing platforms. Molecular Biology and Evolution. 35: 1547-1549.

Larkin, A., M. Blackshields, Gordon Brown, Nigel Chenna, Ramu McGettigan, Paul Mcwilliam, Hamish Valentin, Franck M. Wallace, Iain Wilm, Andreas Lopez, Rodrigo Thompson, Julie J. Gibson, Toby G. Higgins, Desmond. (2007). Clustal W and Clustal X version 2.0.Bioinformatics. 23. 2947-2948.

Miller, R.N.G., M. Holderness, P.D. Bridge, G.F. Chung and M.H. Zakaria, 1999. Genetic diversity of Ganoderma in oil palm plantings. Plant Pathol., 48: 595-603.

Moncalvo, JM., Wang, H., Hseu, R., 1995. b - Gene phylogeny of the Ganoder malucidum complex based on ribosomal DNA sequences comparison with traditional taxonomic characters. Mycological Research 99(12), 1489-1499.

Moncalvo, JM., Ryvarden, L., 1998. Nomenclature of Ganoderma taceae. In synopsis Fungorum11, 1-109.

Mueller GM, Shcmit JP, Leacock PR, Buyck B et al. 2007 - Global diversity and distribution of macro fungi. Biodiversity and Conservation 16, 3748.

Muyzer Gerard and Smalla Kornelia. 1998. Application of denaturing gradient gel electrophoresis (DGGE) and temperature gradient gel electrophoresis (TGGE) in microbial ecology. Antonie van Leeuwenhoek. 73: 127-141.

Núñez, M., Ryvarden, L. 2000.East Asian polypores. Synopsis Fungorum. 13:1- 
168.

Pilotti, C.A., F.R. Sanderson and E.A.B. Aitken, 2003. Genetic structure of a population of Ganoderma boninenseon oil palm. Plant Pathol., 52:455-463

Prasher, I.B., 2015. Wood-rotting non-gilled Agaricomycetes of Himalayas. Fungal Diversity Research Series: 1-653

Sudhir Kumar, Glen Stecher, and Koichiro Tamura. 2015. MEGA7: Molecular Evolutionary Genetics Analysis version 7.0. Molecular Biology and Evolution (submitted).

Surcek, M., 1988. The illustrated book of mushrooms and fungi. Octopus Book, London. 311 pp.

Sun S. J, Gao W, Lin S. Q, Zhu J, Xie B. G, Lin Z. 2006. B. Analysis of genetic diversity in Ganoderma populations with a novel molecular marker SRAP. Appl Microbiol Biotechnol. 72:53743.

Hall, T.A., 1999. BioEdit: a user-friendly biological sequence alignment editor and analysis program for Windows 95/98/NT. Nucl. Acids. Symp. Ser. 41:95-98.

Hong, K.J, Dunn, D.M., Shen, C. L., Pence B. C. 2004. Effects of Ganoderma lucidum on apoptotic and antiinflammatory function in HT-29 human colonic carcinoma cells. Phytother Res; 18: 768-70.
Hseu, R.S., Wang H.H, Wang, H. F, Moncalvo, J.M., 1996. Differentiation and grouping of isolates of Ganoderma lucidum complex by random amplified polymorphic DNAPCR compared with grouping on the basis of internal transcribed spacer sequences. Appl Environ Microbiol. 62: 1354-63.

Wasser, P. and Weis, L. 1999. Medicinal Properties of Substances Occurring in Higher Basidiomycetes Mushrooms: Current Perspectives. International Journal of Medicinal Mushrooms, 1, 31-62.

White, Tl., Bmns, T, Lee, S. and Taylor, 1 1990.Amplification and direct sequencing of fungal ribosomal RNA genes for phylogenetics. In: peR Protocols: A Guide to Methods and Applications (eds. M.A Innis, D.H. Gelfand, II Sninsky and TJ. White) Academic.

Zheng. L., Jia. D., Fei, X., Luo, X., Yang Z.2009. An assessment of the genetic diversity within Ganoderma strains with AFLP and ITS PCR-RFLP. Microbiol Res. 164:312-21.

Zothanzama, J., Josiah, M.C.V., Robert, A.B., and Benjamin, W.H. 2017.Ganoderma mizoramense, Persoonia - Volume 38,pp 326-327.

\section{How to cite this article:}

Zohmangaiha, Josiah MC. Vabeikhokhei, John Zothanzama and Lalrinawmi, H. 2019. Ganoderma Species of Mizoram, India. Int.J.Curr.Microbiol.App.Sci. 8(04): 2871-2879. doi: https://doi.org/10.20546/ijcmas.2019.804.335 